\title{
Predicting Innovative Behavior Among Employees in a Manufacturing Company: The Role of Psychological Capital
}

\author{
Ika Zenita Ratnaningsih, Anggun Resdasari Prasetyo, and Unika Prihatsanti \\ Faculty of Psychology \\ Universitas Diponegoro
}

\begin{abstract}
The aim of this study is to investigate the relationship between psychological capital and workplace innovative behavior. The importance of innovative behavior in the competitive business world has been widely recognized. Previous studies have examined variables related to innovative behavior both at personal and organizational levels; however, there is a paucity of research looking at psychological capital as the predictor of workplace innovative behavior. In this study psychological capital and innovative behavior of 149 non-managerial employees in an apparel manufacture company were measured using Psychological Capital Scale (20 items, $\alpha=.872$ ) and Innovative Behavior Scale (nine items, $\alpha=.874$ ). The regression analysis shows a significant positive correlation between these two variables $(r=.519, p<.01)$ and $27 \%$ of variance in innovative behavior can be explained from psychological capital. The results are discussed in relation to its theoretical contribution and practical implications in organizational contexts.
\end{abstract}

Keywords: innovative behavior, psychological capital, manufacture

Penelitian ini bertujuan untuk mengetahui hubungan antara psychological capital dan perilaku inovatif di tempat kerja. Perilaku inovatif berperan penting dalam dunia bisnis yang semakin kompetitif. Penelitian sebelumnya telah meneliti variabel-variabel yang berhubungan dengan perilaku inovatif, baik pada tingkat individual maupun organisasional, namun belum ada penelitian yang menguji hubungan antara psychological capital dan perilaku inovatif. Subjek penelitian berjumlah 149 karyawan non-manajerial setingkat group leader di perusahaan yang bergerak di bidang manufaktur garmen. Alat ukur yang digunakan terdiri atas dua buah skala psikologi, yaitu Skala Perilaku Inovatif (sembilan butir, $\alpha=.874$ ) dan Skala Psychological Capital (20 butir, $\alpha=.872$ ). Hasil pengujian hipotesis dengan analisis regresi sederhana menunjukkan bahwa terdapat korelasi yang positif dan signifikan antara psychological capital dan perilaku inovatif $(r=.519, p<.01)$. Psychological capital memiliki sumbangan efektif $27 \%$ terhadap variabel perilaku inovatif di tempat kerja. Temuan tersebut didiskusikan di artikel ini dalam kaitannya dengan kontribusi teoretis dan implikasi praktis untuk organisasi.

Kata kunci: perilaku inovatif, psychological capital, manufaktur

The business world is a competitive world. Global flow of products, services, and labour in the free market has increased the pressure for businesses to be more competitive. This situation drives companies to develop their own unique competitive advantages. To this end, innovations in both product and service are crucial (Ancok, 2012). As also noted by Pundt, Martins, and Nerdinger (2010), innovation is imperative for companies to survive in this ever-changing world.

Correspondence concerning this article should be addressed to Ika Zenita Ratnaningsih, Faculty of Psychology Universitas Diponegoro, Jalan Prof. Sudharto, S.H. Tembalang, Semarang. E-mail: ikazenita@ yahoo.com
A rapid change in an organization's strategic environment may cause major problems which can decrease performance if there is no innovative capability within the organization (De Jong \& Hartog, 2007). Organizations that identify themselves with innovation and innovative culture tend to encourage and provide information about innovation to their employees (Poulton, 2005). Innovative organizations manage environmental challenges quicker and more easily (Damanpour \& Gopalakrishnan, 1998).

The 2014 Global Innovation Index indicates that Indonesia is in the 87 th position among 143 countries surveyed. This position is considerably lower than its 
neighbouring countries such as Malaysia and Singapore. Considering its potential as a major consumer in South East Asia, Indonesia should be able to innovate more creatively as compared to the current condition.

Many organizations still use outdated and ineffective ways in conducting their business, simply following what they have done in the past. Efforts are usually focused on improving these outdated ways, and not on attempting to see problems from a different angle. Currently, many organizations have started to include innovation in their vision and mission statement. One of the key innovations crucial in this competitive business world is the innovation in human resource management. The condition and management of human resources determine the company's competitive advantages (Simamora, 2004). As also argued by Hasibuan (2000), human resource is an invaluable asset for a company to achieve its goals.

Innovation adds values to product, service, work process, marketing, distribution, and policy, not only for the company but also for stakeholders and the society. The scope of innovation in an organization ranges from the development and implementation of new ideas which affect the theory, practice, and product to improvements of everyday work design and process in a smaller scale (Axtell et al., as cited in Janssen, 2004). Research on organizational innovation can be conducted on three different levels, namely, individual, group, and organizational level. Innovation on individual level is called innovative behavior (Helmi, 2011).

According to West and Farr (cited in Janssen, 2004), innovative behavior is the intention to create, introduce, and apply new ideas aimed at optimizing group and organizational performance. Scott and Bruce (1994) described workplace innovative behavior as a complex behavior consisted of different behavioral tasks, namely, idea generation, idea promotion, and idea realization. Moreover, Scott and Bruce explained that innovative behavior is an individual's intention expressed in their work, group, and organization.

Innovative behavior is defined as an individual's action directed at the emergence, introduction, and application of new ideas which benefited the organization at all levels (Kleysen \& Street, 2001). Innovation includes new ideas which aimed at improving work relations or the application of new ideas or new technologies which significantly improve work efficiency and effectiveness. Innovative behavior is employees' intention to create, introduce, and apply new ideas in groups or organisations, which intended to optimize group's and organisation's performance (Yuan \& Woodman, 2010).
Often conflated with creativity, innovation involves a more complex process because it also focuses on the application of ideas generated. Innovative behavior is a tendency to create new ideas, a tolerance towards ambiguity, which is marked by the willingness to be effective, and oriented to achievement. Kleysen and Street (2001) stated that innovative behavior involves five components, namely, exploration of opportunities, generativitity, formative investigation, efforts to be the best, and application. Aspects of innovative behavior are idea generation, idea promotion, and idea realization.

Innovative behavior is not an inherited condition, rather, all humans have the potential to innovate particularly within a supportive climate. Research has shown that individual's innovative capability at workplace is important to nurture the organisation's innovation (De Jong \& Hartog, 2007). Riyanti's (cited in Hutahaean, 2005) study indicated a direct effect of organization innovation on the business' success. Accordingly, Dörner (2012) also explained that innovative behavior at workplace can predict work performance.

Previous studies have identified several factors affecting innovative behavior, namely, personal factors and organizational factors. Personal factors include intrinsic motivation (Helmi, 2011), openness to experience (Yesil \& Sozbilir, 2013), and educational level (Etikariena \& Muluk, 2014; Baumann, 2011). Organizational factors include trust, transformational leadership (Reuvers, Van Engen, Vinkenburg, \& WilsonEvered, 2008), access to information technology, knowledge sharing (Helmi, 2011), organizational climate (Scott \& Bruce, 1994), organizational support (Cingöz \& Akdoğan, 2011), supervisor's gender (Reuvers et al), flexible job design (Dorenbosch, Van Engen, \& Verhagen, 2005), and organizational memory (Etikariena \& Muluk, 2014).

Previous studies on innovative behavior have been conducted among entrepreneurship students (Helmi, 2011), hotel employees (Yesil \& Sozbilir, 2013), health service workers (Janssen, 2004), radio broadcaster (Kresnandito \& Fajrianthi, 2012), airlines employees (Chrisbiyanto \& Ancok, 2014), telecommunication employees (Maryen \& Ancok, 2012), and teachers (Basrawy $\&$ Susanto, 2012). The current study is conducted among employees in a garment manufacture company.

Innovation as human creation is determined by external and internal factors. One of the internal factors is the quality of human capital. There are seven components of human capital that need to be developed so that employees may optimally contribute to 
the organization. These components would produce optimal contributions when accompanied by leadership and organizational structure capital which provide supportive working environments. These seven components are creative, intellectual, emotional, social, adversity, moral, and health capital (Ancok, 2012). Another capital which is not less important is psychological capital.

Psychological capital is defined as an individual's psychological capacity characterized by confidence in taking and overcoming challenging tasks (selfefficacy), positive attribution of the current and future success (optimism), aspiration of achieving goals - and if needed finding alternative ways - to achieve goals (hope), and ability to recover quickly when facing difficult challenges or problems (resiliency) (Luthans, Youssef, \& Avolio, 2007).

Psychological capital is relatively new in psychological research and is useful for improving human resource management in order to increase organizational performance and competitiveness (Luthans, Youssef \& Avolio, 2007). Psychological capital may enhance competition in achieving organisation's profit by identifying full potentials of the human resources within the organisation. Cetin (2011) stated that psychological capital can predict organizational commitment and job satisfaction. T. D. Nguyen and T. T. Nguyen's (2012) study indicated positive correlation between psychological capital, work performance, and work-life quality.

Based on the argument that innovative behavior can be developed, this study seeks to investigate the correlation between psychological capital and workplace innovative behavior.

\section{Method}

Participants in this study were 149 employees in an export-oriented clothing manufacturing company in Semarang, Indonesia. The demography of the participants is presented in Table 1. Participants were recruited through a non-probability sampling - technique, namely, purposive sampling (Sugiyono, 2005). Recruitment criterium was a minimum of one year work experience in this company, so that the participants had reasonable knowledge about the conditions within the company. Allen \& Meyer (cited in Noordin, Rahim, Ibrahim, \& Omar, 2011) noted that at this stage an employee has been through the introductory phase of their work in a certain company. Participants were non-managerial employees and
Table 1

Participants' Demographic Data

\begin{tabular}{llr}
\hline \multicolumn{1}{c}{$\begin{array}{c}\text { Demographic } \\
\text { Variable }\end{array}$} & \multicolumn{1}{c}{ Category } & $N$ \\
\hline Gender & Female & 140 \\
& Male & 9 \\
Age & < 20 years old & 9 \\
& 20- 40 years old & 138 \\
& $>$ 40 years old & 2 \\
Education & Junior High School & 25 \\
& Senior/Vocational High & 112 \\
& School & \\
& College (Diploma \& & 12 \\
Marital Status & Bachelor Degree) & \\
& Unmarried & 45 \\
Work Experience & Married & 104 \\
& $>2$ years & 56 \\
& $1-2$ year(s) & 93 \\
\hline
\end{tabular}

Table 2

Descriptive Statistics

\begin{tabular}{llcc}
\hline \multicolumn{1}{c}{ Variable } & & $\begin{array}{c}\text { Hypothetical } \\
\text { Score }\end{array}$ & $\begin{array}{c}\text { Empirical } \\
\text { Score }\end{array}$ \\
\hline Innovative & Minimum & 9 & 11 \\
Behavior & Maximum & 36 & 36 \\
& $M$ & 33.5 & 24.92 \\
& $S D$ & 4.5 & 4.871 \\
Psychological & Minimum & 20 & 58 \\
Capital & Maximum & 120 & 117 \\
& $M$ & 70 & 86.69 \\
& $S D$ & 16.67 & 11.441 \\
\hline
\end{tabular}

at least at the group leader level.

Data in this study were collected using inventory methods to generate participants' responses. The instruments were Innovative Behavior Scale and Psychological Capital Scale. The Innovative Behavior Scale (nine items, $\alpha=.874$ ) was based on Scott and Bruce's (1994) and Janssen's (2000) studies that have been adapted by Etikariena and Muluk's (2014) study. This scale consists of three dimensions of innovative behavior, which are idea generation, idea promotion, and idea realization. Participants' were asked to respond from 1 (never) to 4 (always).

The Psychological Capital Scale (20 items, $\alpha=$ .872) was adapted from the Psychological Capital Questionnaire developed by Luthans, Avolio, Avey and Norman (cited in Luthans, Youssef, \& Avolio, 2007). It measures psychological capital using four constructs: self-efficacy, optimism, hope, and resi- 
lience. The response ranged from 1 (not relevant) to 6 (very relevant).

Data were analyzed using simple regression analysis to examine the correlations between variables and the proportion of variance in innovative behavior predictable from psychological capital. According to Sugiyono (2005), regression analysis is one of the statistical techniques to measure correlation between two or more variables both causal and functional relationships.

\section{Results}

\section{Descriptive Statistics}

The descriptive statistics of the data in this study is presented in Table 2. Table 2 reveals the empirical mean of both variables are higher than their hypothetical mean. This shows that participants' innovative behavior and psychological capital are relatively high. Categorisations were created based on the general description of these scores. It is concluded that in general employees in this company have a high score of innovative behavior and psychological capital.

\section{Hypothesis Testing}

The analysis shows a significant positive correlation between psychological capital and workplace innovative behavior $(r=.519, p<.001)$. This finding supports the research hypothesis that there is a correlation between psychological capital and employees' innovative behavior. Positive direction of the correlation indicates that the higher the psychological capital, the higher the employees' innovative behavior. The coefficient of determination .270 shows that psychological capital contributes $27 \%$ to innovative behavior. It is concluded that psychological capital is a predictor of workplace innovative behavior.

\section{Discussion}

The finding shows a significant correlation between psychological capital and workplace innovative behavior $(r=.519, p<.01)$. Twenty seven percent of variance in innovative behavior can be predicted by psychological capital. This result indicates that one of the individual factors contributing to workplace innovative behavior is psychological capital. Psychological capital is defined as an individual's psychological capacity which is characterized by confidence in taking and overcoming challenging tasks (self-efficacy), positive attribution of the current and future success (optimism), aspiration of achieving goals - and if needed finding alternative ways to achieve goals (hope), and ability to recover quickly when facing difficult challenges or problems (resiliency) (Luthans, Youssef, \& Avolio, 2007).

A meta-analysis by Avey, Reichard, Luthans, and Mhatre (2011) identified that psychological capital affects employees' positive work attitudes (job satisfaction, organizational commitment, psychological wellbeing), employees' positive work behavior (organizational citizenship behaviour), and work performance. In accordance with this and the finding of the current study, psychological capital has also been identified as one of the predictors of workplace innovative behavior (Wojtczuk-Turek \& Turek, 2015; Jafri, 2012). Individuals who have positive attitude and confidence of their capability will be able to contribute thoughts and ideas to achieve goals. This is also supported by positive attitude and hope to achieve a better future, so that individuals will keep trying to introduce and implement new ideas.

This study is also in accordance with Pryce-Jones' (2010) argument that psychological capital can help increasing employees' motivation, persistence, and creative thinking in stressful situations. This is possible because employees with high psychological capital adapt better, are more resilient, and have hope; which in return produces strong motivation to find alternative ways to achieve success in their workplace.

Table 3

Correlations Between and Contributions of Each Dimension of Psychological Capital to Innovative Behavior

\begin{tabular}{lccc}
\hline \multicolumn{1}{c}{ Variable } & Correlation $(r)$ & Contribution & Interpretation \\
\hline Psychological capital \& Innovative Behavior & $.519^{* *}$ & $27 \%$ & Average \\
Self-Efficacy \& Innovative Behavior & $.570^{* *}$ & $32.5 \%$ & Average \\
Hope \& Innovative Behavior & $.336^{* *}$ & $11.3 \%$ & Average \\
Resilience \& Innovative Behavior & $.390^{* *}$ & $15.2 \%$ & Average \\
Optimism \& Innovative Behavior & $.211^{*}$ & $4.5 \%$ & Low \\
\hline Note. **) Correlation is significant at $p=.000(p<.001)$ & & &
\end{tabular}


Table 3 presents the recapitulation of correlations between each dimension of psychological capital and innovative behavior. In general psychological capital shows correlation with innovative behavior on an average level. In analyzing each dimension of psychological capital, the largest contribution is from selfefficacy. This means that individuals' confidence in their own ability is important for enabling individuals to think and produce new ideas (idea generation). Such individuals are also confident in expressing their ideas (idea promotion), and courageous in implementing their ideas (idea realization).

In general participants in this study are individuals with positive characteristics such as confident, optimistic, hopeful, and are able to recover quickly from difficult situations. These characteristics show that participants are resilient and reliable individuals particularly in the face of problems. They will strive, and not give up.

Further analyses on participants' demographic data reveal that age, education, and gender do not correlate with workplace innovative behavior. This result supports Hilmi, Pawanchik, Mustapha, and Mahmud's (2012) study which found that there is no significant difference in innovative behavior based on gender. Moreover, a study by Reuvers et al. (2008) also found that manager's gender does not affect workplace innovative behavior.

Different from the current finding which indicates no correlation between educational level and workplace innovative behavior, Scott and Bruce (1994) and Baumann (2011) claimed that educational level is a strong predictor of workplace innovative behavior. This difference can be explained by looking at the details of the educational level. Participants in this study are quite homogenous, with the majority completed Junior High School and High School. Employees with Junior High School qualification generally have worked longer. Only a small minority of participants have a college degree.

Regarding organizational characteristics, this clothing company is relatively new but growing rapidly. At this stage, the company develops and expands so that employees' organizational commitment is of paramount importance (Jones, 1994). To this end, the company has conducted different levels of training and development programmes.

\section{Limitations}

There are some limitations of this study, particularly in relation to participants. The small sample size from only one company might not enable a generalization on a larger population or different types of company. Future research is needed to explore other contexts and scopes.

\section{Conclusion and Recommendation}

This study contributes to the knowledge on personal factors that influence workplace innovative behavior, namely, psychological capital. Regression analysis indicates a significant correlation between psychological capital and workplace innovative behavior $(r=.519, p<.01)$ and $27 \%$ of variance in workplace innovative behavior is predictable from psychological capital. Demographic variables such as age, gender, and education do not correlate with workplace innovative behavior. Additionally, the findings of this study also show that workplace innovative behavior is relatively high among employees in this clothing manufacturing company. Theoretically, this research support the notion that innovative behavior in an organization can be improved particularly at individual level, and identified a factor at play, that is, psychological capital.

Considering the significant contribution of psychological capital for innovative behavior, it is recommended for companies to take into account employee's level of psychological capital during recruitment. Training and development programmes for employees may also be directed to enhance their psychological capital. Future research can extend this study on other industries, and may investigate possibilities of mediating variables or other variables which can predict workplace innovative behavior.

\section{References}

Ancok, D. (2012). Psikologi kepemimpinan dan inovasi (Leadership psychology and innovation). Jakarta: Erlangga.

Avey, J. B., Reichard, R. J., Luthans, F., Mhatre, K. H. (2011). Meta-analysis of the impact of positive psychological capital on employee attitudes, behaviors and performance. Human Resource Development Quarterly, 22(2), 127-152.

Basrawy, I. F., Susanto, F. (2012). Pengaruh kecerdasan emosional dan motivasi intrinsik terhadap perilaku inovatif guru SD (The effects of emotional intelligence and intrinsic motivation on elementary school teachers' innovative behaviour) (abstract of an unpublished thesis). Magister Manaje- 
men, Universitas Gadjah Mada.

Baumann, P. K. (2011). The relationship between individual and organizational characteristics and nurse innovation behavior (Unpublished dissertation). School of Nursing Indiana University.

Cetin, F. (2011). The effects of the organizational psychological capital on the attitudes of commitment and satisfaction: A public sample in Turkey. European Journal of Social Science, 21(3), 373-384.

Chrisbiyanto, A., Ancok, D. (2014). Pengaruh persepsi gaya kepemimpinan transformasional, budaya inovasi perusahaan, dan tipe kepribadian openness to experience terhadap perilaku inovatif karyawan studi empirik pada PT. Garuda Indonesia (Persero) Tbk (The effects of the perception of transformational leadership style, organizational innovative culture, and openness to experience personality type on employees' innovative behavior: An empirical study on Garuda Indonesia, Ltd.) (Abstract of an unpublished thesis). Magister Manajemen, Universitas Gadjah Mada.

Cingöz, A., \& Akdoğan, A. A. (2011). An empirical examination of performance and image outcome expectation as determinants of innovative behavior in the workplace. Procedia Social \& Behavioral Sciences, 24, 847-853. doi: 10.1016/j.sbspro.2011.09.099

Damanpour, F., \& Gopalakrishnan, S. (1998). Theories of organizational structure and innovation adoption: The role of environmental change. Journal of Engineering and Technology Management, 15, 1-24.

De Jong, J. P. J., \& Den Hartog, D. N. (2007). How leaders influence employees' innovative behaviour. European Journal of Innovation Management, 10 (1), 41-64. doi: 10.1108/ 14601060710720546

Dorenbosch, L., Van Engen, L., \& Verhagen, M. (2005). On-the-job innovation: The impact of job design and human resource management through production ownership. Creativity and Innovation Management, 14(2), 129-141.

Dörner, N. (2012). Innovative work behavior: The roles of employee expectations and effects on job performance (Unpublished dissertation). School of Management, Economics, Law, Social Sciences and International Affair. University of St.Gallen.

Etikariena, A., \& Muluk, H. (2014). Hubungan antara memori organisasi dan perilaku inovatif karyawan (Relationship between organizational memory and employees' innovative behavior). Makara Hubs-Asia, 18(2), 77-88, doi: 10.7454/mssh.v18i2.xxxx

Hasibuan, M. S. P. (2000). Manajemen sumber daya manusia (Human resources management). Jakarta: Bumi Aksara.
Helmi, A. F. (2011). Model determinan perilaku inovatif pada mahasiswa yang berwirausaha (Determination model of innovative behavior among entrepreneur college students). Jurnal Psikologi, 38(2), 134-146.

Hilmi, M. F., Pawanchik, S., Mustapha, Y., \& Mahmud, N. (2012). Innovative behavior of Malaysian employees: An exploratory study. Proceeding of International Conference on Innovation, Management and Technology Research (ICIMTR2012), Malacca, Malaysia 21-22 May.

Hutahaean, E. S. (2005). Kontribusi pribadi kreatif dan iklim organisasi terhadap perilaku inovatif (Contribution of creative personality and organizational climate for innovative behavior). Proceeding Seminar Nasional PESAT, Universitas Gunadarma, Jakarta.

Jafri, H. (2012). Psychological capital and innovative behaviour: An empirical study on apparel fashion industry. The Journal Contemporary Management Research, 6(1), 42-52.

Janssen, O. (2000). Job demands, perceptions of effort-reward, fairness and innovative work behavior. Journal of Occupational and Organizational Psychology, 73, 287-302.

Janssen, O. (2004). How fairness perceptions make innovative behavior more or less stressful. Journal of Organizational Behavior, 25, 201-215. doi: 10. 1002/job.238

Jones, G. R. (1994). Organization theory, test and cases (2nd ed.). Boston: Addison Wesley: Longman Publishing Company, Inc.

Kleysen, R. F., \& Street, C. T. (2001). Toward a multi-dimensional measure of individual innovative behaviour. Journal of Intellectual Capital, 2(3), 1469-1930.

Kresnandito, A. P., \& Fajrianthi. (2012). Pengaruh persepsi kepemimpinan transformasional terhadap perilaku inovatif penyiar radio (The effects of the perception of transformational leadership on broadcasters' innovative behavior). Jurnal Psikologi Industri dan Organisasi, 1(2), 78-85.

Luthans, F., Youssef, C. M., \& Avolio, B. J. (2007). Psychological capital: Developing the human competitive edge. New York: Oxford University Press

Maryen, A. S., Ancok, D. (2012). Pengaruh iklim kreatif, kepemimpinan transformasional dan persepsi keragaman tim terhadap perilaku kerja inovatif pada PT. Telkom area Yogyakarta (The effects of creative climate, transformational leadership, and perception of team diversity on innovative work behavior in Telkom Yogyakarta, 
Ltd.). (Abstract of an unpublished thesis). Magister Manajemen Universitas Gadjah Mada.

Nguyen, T. D., \& Nguyen, T. T. (2012). Psychological capital, quality of work life and quality of life marketers: Evidence from Vietnam. Journal of Macromarketing, 32(1), 87-95.

Noordin, F., Rahim, A. R., Ibrahim, A. H., \& Omar, M. S. (2011). An analysis of career stages on organizational commitment of Australian managers. International Journal of Business and Social Sciences, 2(17), 117-126.

Poulton, M. S. (2005). Organizational story telling, ethics and morality: How stories frame limits of behavior in organizations. Electronic Journal of Business Ethics and Organizational Studies, 10(2), 500-509.

Pryce-Jones, J. (2010). Happines at work: Maximizing your psychological capital for success. Chichester: John Wiley \& Sons Ltd.

Pundt, A., Martins, E., \& Nerdinger, F. W. (2010). Innovative behavior and reciprocal exchange between employees and organization. Zeitschift fur Personalforschung, 24(2), 173-193.

Reuvers, M., Van Engen, M. L., Vinkenburg, C. J., \& Wilson-Evered, E. (2008). Transformational leadership and innovative work behavior: Exploring the relevance of gender differences. Creativity and Innovation Management, 17(3), 227-244. doi.10.1 11/ j.1467-8691.2008.00487

Scott, S. G., \& Bruce, R. A. (1994). Determinants of innovative behavior: A path model of individual innovation in the workplace. The Academy of $\mathrm{Ma}$ nagement Journal, 37(3), 580-607.

Simamora, H. (2004). Manajemen sumber daya manusia (Human resources management) ( $3 \mathrm{rd} \mathrm{ed}$.). Yogyakarta: Bagian Penerbitan STIE YKPN.

Sugiyono (2005). Statistika untuk penelitian (Statistics for research). Bandung. Alfabeta.

Yesil, S., Sozbilir, F. (2013). An empirical investigation into the impact of personality on individual innovation behaviour in the workplace. Procedia Social \& Behavioral Sciences, 81, 540-551.

Yuan, F., \& Woodman, R. W. (2010). Innovative behavior in the workplace: The role performance and image outcomes expectation. Academy of Management Journal, 53(2), 323 - 343

Wojtczuk-Turek, A., \& Turek, D. (2015). Innovative behaviour in the workplace: The role of HR flexibility, individual flexibility and psychological capital. In the case of Poland. European Journal of Innovation Management, 18(3). 397-419. Doi: http://dx.doi.org/10.1108/EJIM-03-2014-0027 